\title{
Soil Characteristics Related to Production on Subclover-Grass Range
}

\author{
MILTON B. JONES, WILLIAM A. WILLIAMS, AND CHARLES E. VAUGHN
}

\section{Abstract}

In northwestern California moisture is usually not limiting for range production during the annual winter-spring growing season. It is, therefore, important to understand how other site factors, both physical and chemical, affect range production. Ridge regression analysis and simple correlations were used to evaluate range production as related to site slope and elevation; soil depth, texture, bulk density, water holding capacity, and pH; and several chemical measures of soil fertility including available $P$ and $S$, exchangeable cations, total $\mathbf{N}$ and $S$, and organic matter. Subclover (Trifolium subterraneum L.) - grass production was measured at 17 typical range sites for 4 fertilizer treatments: $P_{0} S_{0}$, $\mathbf{P}_{300} \mathbf{S}_{0}, \mathbf{P}_{0} \mathbf{S}_{90}, \mathbf{P}_{300} \mathbf{S}_{90}$ (subscripts $=\mathrm{kg} / \mathrm{ha}$ ). When no fertilizer was applied, soil pH and available $P$ appeared to be the 2 variables most closely related to yield. Forage production increased when $\mathbf{P}$ and $S$ fertilizers were applied. When $P$ was applied, exchangeable soil $K$ was the most important variable related to yield; and when $S$ was applied, available $P$ was the variable most closely related to production. When $P$ and $S$ were applied together, available $P$ and $K$ were most closely related to yield. While there was generally a striking response to applied $S$, our measures of available soil $S$ were poorly related to production.

The annual-type rangelands of California are very extensive, occupying roughly $24 \%$ of the state including both treeless and wooded areas (Love 1955). Annual plant growth commences with the first fall rain (usually in late October), continues slowly through the winter, and is very rapid for about 6 weeks beginning in early March. During the 6-month growing period soil water is not generally the limiting factor (Martin and Berry 1970). It is known that nitrogen (N), phosphorus (P), and sulfur (S) are limiting in varying degrees (Martin 1958, Jones 1974) because of the large increases in herbage production that usually occur when these elements are applied. However, various measures of soil fertility and soil-site physical characteristics and the relative importance of each to range production have not been evaluated. Northwestern California is ideal for such an evaluation due to the variability in soils, elevation, and slopes on the upland annual ranges.

The purpose of this paper is to report an evaluation of chemical and physical characteristics of soils on range sites sown to subclover (Trifolium subterraneum L.) with and without $P$ and $S$ fertilization, and to determine the relative importance of these factors as they relate to annual grass-subclover yields.

\section{Materials and Methods}

The study was conducted in coastal California $160 \mathrm{~km}$ north of San Francisco, on and near the University of California Hopland Field Station. Seventeen typical annual rangeland locations

The authors are agronomist, professor (Davis), and staff research associate, Department of Agronomy and Range Science, University of California, Hopland Field station, Hopland, Calif. 95449.

Authors thank K. Mayalagu for assistance with soil classification, J. Blackard for soil physical analysis, and B. San Diego for assistance in the field

Manuscript received November 23, 1981. representing 3 soil series were studied: 9 Sutherlin series soils (Ultic Haploxeralfs), 5 Laughlin series soils (Ultic Haploxerolls), and 3 Josephine series soils (Typic Haploxerults). None of the sites had received any prior fertilization. Some of the chemical and physical characteristics of the soils are shown in Table 1.

At each location experiments were established in September 1975 after they were mowed, raked, and disced. Inoculated subclover was seeded at $100 \mathrm{~kg} / \mathrm{ha}$. Resident annual vegetation, mainly Bromus mollis, Festuca megalura, and Erodium botrys, grew naturally. Phosphorus was applied as S-f ree concentrated superphosphate $(22.9 \% \mathrm{P})$ at rates of $0,12.5,18.8,25,37.5,50,100$, 200 , and $300 \mathrm{~kg} /$ ha elemental $P$. Sulfur was applied uniformly at 90 $\mathrm{kg} / \mathrm{ha}$ as 100 -mesh elemental $S$ to all levels of $P$, except that the 0 and $300 \mathrm{~kg} /$ ha $P$ treatments were repeated with no $S$. All fertilizer treatments were replicated twice in $0.9 \times 1.5-\mathrm{m}$ plots in a randomized complete block design at each of the 17 sites. Yield values in this paper are reported only for the $\mathrm{P}_{0} \mathrm{~S}_{0}, \mathrm{P}_{300} \mathrm{~S}_{0}, \mathrm{P}_{0} \mathrm{~S}_{90}$, and $\mathrm{P}_{300} \mathrm{~S}_{90}$ treatments. Each treatment was sampled in late April 1976 by clipping the subclover-annual grass herbage at ground level from one $30 \times 91-\mathrm{cm}$ quadrat in each replication. The whole sample was dried to a constant weight at $60^{\circ} \mathrm{C}$ and weighed.

The relationship of forage production to 22 soil chemical and physical properties and site characteristics were evaluated by using a simple correlation matrix and by ridge regression, a method of ameliorating problems of unstable regression coefficients resulting from highly correlated variables-multi-collinearity (Williams et al. 1979). The variables were soil organic matter (OM), total $\mathrm{N}$ and $\mathrm{S}$, total and available $\mathrm{S}$ and $\mathrm{P}$, exchangeable $\mathrm{Ca}, \mathrm{Mg}, \mathrm{K}$, and $\mathrm{Na}$, soil $\mathrm{pH}$, water at $1 / 3$ and 15 atmospheres, bulk density, percent sand, silt, clay and gravel, depth of $A$ and $B$ horizons, site elevation, and \% slope. Available soil water was taken as $\%$ water at $1 / 2$ atmosphere minus $\%$ water at 15 atmospheres. The ratios of the various elements were calculated and their relationships to yields evaluated. These correlation and regression analyses were run independently on each of the fertilizer treatments.

A composite soil sample was taken from the surface 0 to $15 \mathrm{~cm}$ from each of the 17 sites before treatments were imposed. These samples were air-dried and passed through a $2-\mathrm{mm}$ sieve before chemical analysis. Soil profile characteristics were determined from a pit dug beside each plot site.

Soil OM was determined by a Walkley-Black titration (Kauffman and Gardner 1976), and total soil N by a Kjeldahl procedure modified to include nitrates (Bremner 1965). Soil-extract S was analyzed by the methylene blue colorimetric procedure of Johnson and Nishita (1952), total S following a nitric-perchloric acid digestion and available $S$ following extraction with $0.01 \mathrm{M} \mathrm{Ca}\left(\mathrm{H}_{2} \mathrm{PO}_{4}\right)_{2}$ (Barrow 1967). Available $P$ was determined by the Bray and Kurtz (1945) number 1 method (Bray-1 P) which is more closely correlated with plant yield and $P$ uptake than other methods on these range sites (Vaughn and Jones 1980). Exchangeable $\mathrm{Ca}, \mathrm{Mg}, \mathrm{K}$, and $\mathrm{Na}$ were determined by atomic absorption spectrophotometry following extraction with neutral $N$ ammonium acetate. Soil pH was measured in a 1:2.5 soil:water suspension. 


\section{Results and Discussion}

There was a wide range in soil-site characteristics and forage production from the 17 sites (Table 1) giving rise to the possibility of sorting out the factors most closely related to yield variations with and without $\mathrm{P}$ and $\mathrm{S}$ applications. This possibility was enhanced by the fact that soil test values for $P, K$, and $S$ ranged from below to above published critical levels. Gard ner et al. (1979) indicated possible responses of subclover to $\mathrm{P}$ with Bray- $1 \mathrm{P}$ test values up to $30 \mathrm{ppm}$, and responses to $K$ with exchangeable $K$ values up to $0.38 \mathrm{meq} / 100 \mathrm{~g}$ soil. Our lowest value of $3 \mathrm{ppm}$ available $S$ was considered low and $19 \mathrm{ppm}$ was considered high (Reisenauer 1975). Gardner et al. (1979) also suggested that when exchangeable $\mathrm{Mg}$ was less than $0.8 \mathrm{meq} / 100 \mathrm{~g}$ soil $(0.8$ was our lowest value) that application of $\mathrm{Mg}$ should be made for increased production. They also suggested that lime be applied when $\mathrm{pH}$ was less than 5.5. We only had one value less than this, at 5.3.

Table 1. Mean and range of values for 17 annual rangeland locations for soil-site characteristics and forage yields. ${ }^{1}$

\begin{tabular}{lrrr}
\hline \hline Soil characteristic & Mean & Minimum & Maximum \\
\hline Total N (\%) & 0.27 & 0.19 & 0.47 \\
Bray-1 P (ppm) & 20 & 4 & 49 \\
Total S (ppm) & 168 & 116 & 285 \\
Available S (ppm) & 7 & 3 & 19 \\
Exch. K (meq/100 g) & 0.48 & 0.29 & 0.82 \\
Exch. Ca (meq/ 100 g) & 4.5 & 2.6 & 7.8 \\
Exch. Mg (meq/100 g) & 4.2 & 0.8 & 13.0 \\
Organic matter (\%) & 5.3 & 3.1 & 8.6 \\
pH & 5.8 & 5.3 & 6.4 \\
Available $\mathrm{H}_{2} 0(\%)$ & 14.5 & 9.8 & 18.2 \\
A horizon depth (cm) & 28 & 5 & 66 \\
Slope (\%) & - & 2 & 20 \\
Elevation (m) & - & 150 & 800 \\
Soil texture & - & $109 m$ & clay loam \\
Yields (kg/ha) & & & \\
PoS & 1,530 & 360 & 2,830 \\
P $_{300} S_{0}$ & 4,300 & 2,870 & 6,310 \\
PoS & 2,870 & 750 & 6,240 \\
P $_{300} S_{90}$ & 4,920 & 3,370 & 7,810 \\
\hline
\end{tabular}

'Soil-site characteristics were measured prior to fertilization.

Simple correlations indicated that Bray-1 P and exchangeable $\mathbf{K}$ were the only two soil characteristics that were positively associated with yields for each of the $\mathbf{4}$ fertilizer treatments. The relationship of available $P$ to yield was expected, but we know of no prior studies indicating that $K$ might be low enough on northern California rangelands for exchangeable $K$ values to be significantly related to production. The correlations of ratios of available $P$ and $\mathrm{S}$, exchangeable cations, and total $\mathrm{N}$ and $\mathrm{S}$ with yield were also examined. Exchangeable $K /$ total $N$ was the only ratio that had a higher correlation with yields from $\mathbf{P}$ and $\mathbf{S}$ fertilized plots than either factor alone. The reason for this is not understood, but the fact that $r$ values were high $(P<.01)$ makes the exchangeable $\mathrm{K} /$ total $\mathrm{N}$ ratio of interest for future study.

The correlation of yield with Bray-1 $\mathbf{P}$ was much higher with $\mathbf{S}$ applications $(r=0.82)$ than without $S(r=0.59)$. The regression equations were $y=19.7+2.96 \mathrm{P}$, and $\mathrm{y}^{\prime}=22.7+0.98 \mathrm{P}$, respectively, where $y=$ yield of $P_{0} S_{90}$ plots, $y^{\prime}=$ yield of $P_{0} S_{0}$ plots, and $\mathbf{P}=\mathbf{B r a y}-1 \mathbf{P}$ values. The regression coefficients were significantly different at the $1 \%$ level. Surprisingly, the correlation of yields to Bray-1 $P$ values was as high for the $P$ and $S$ treatment as for $S$ alone, and applying $P$ alone only reduced the correlation slightly compared to the check treatment. There was a significant response to applied $\mathbf{P}$ at all sites, but sites with higher soil-test $\mathbf{P}$ required less applied $\mathbf{P}$ to reach maximum yields (Jones, unpublished data).

Total soil $\mathrm{N}$ did not show any significant relationship to yield indicating that the $\mathrm{N}$ available to the subclover-grass range was not related to total $\mathrm{N}$ in the soil. We know that $\mathrm{N}$-fixation by clover component of the forage makes a very important contribution to the $\mathrm{N}$ obtained by the plants (Jones et al. 1978, Williams et al. 1977).

Even though $\mathbf{S}$ was shown to be limiting by the yield responses to applied $S$ on 10 of the sites, and there was a wide range of total and available $S$ values (Table 1), no significant relationship between these soil tests and yields was found (Table 2). This indicates that total and available soil $\mathrm{S}$ as measured in this study did not relate to the availability of $S$ to plants. Simila r observations have been made previously on subclover-gra ss pasture soils (Spencer and Glendinning 1980). However, useful diagnostic criteria have been obtained with tissue tests (Jones et al. 1980).

Several of the soil chemical characteristics such as total soil $\mathbf{N}$ and $S$, and $O M$ were highly correlated with each other. Exchangeable $\mathrm{Ca}$ was correlated with $\mathrm{N}$ and $\mathrm{OM}$, and exchangeable $\mathrm{K}$ with $\mathrm{N}$. These relationships indicate multicollinearity and result in inflated and misleading regression coefficients. Thus, the soil-site variables were studied further by use of ridge regression because of the existence of multicollinearity among the retained variables (Williams et al. 1979). The analysis produced standardized partial regression coefficients after adjustment $(k=0.3)$, showing the relative importance of soil variables as related to yields on four

Table 2. Simple correlation coefficients $(r)$ between soil characteristics and annual rangeland yields from 4 fertilizer treatments on 17 locations.

\begin{tabular}{|c|c|c|c|c|c|c|c|c|c|c|c|c|c|}
\hline & $\begin{array}{l}N \\
1\end{array}$ & $\begin{array}{l}\mathrm{P} \\
2\end{array}$ & $\begin{array}{l}\mathbf{K}^{\prime} \\
3\end{array}$ & $\begin{array}{l}S \\
4\end{array}$ & ${ }_{5}^{\text {Avail. S }}$ & $\begin{array}{l}\mathrm{Ca}^{1} \\
6\end{array}$ & $\begin{array}{l}\mathrm{Mgl} \\
7\end{array}$ & $\begin{array}{l}\text { OM } \\
8\end{array}$ & $\begin{array}{l}\text { pH } \\
9\end{array}$ & $\begin{array}{l}\mathrm{H}_{2} \mathrm{O}^{2} \\
10\end{array}$ & $\begin{array}{l}\text { Depth } \\
11\end{array}$ & $\mathrm{NO}_{3}-\mathrm{N}$ & $\mathrm{K}^{1} / \mathrm{N}$ \\
\hline $\begin{array}{l}1 \text { Total N } \\
2 \text { Bray-1 P }\end{array}$ & $\begin{array}{l}1.00 \\
-.11\end{array}$ & 1.00 & & & & & & & & & & & \\
\hline 3 Exch. K & $.64 * *$ & .44 & 1.00 & & & & & & & & & & \\
\hline 4 Total S & $.72^{* *}$ & -.17 & .13 & 1.00 & & & & & & & & & \\
\hline 5 Avail. $S$ & -.17 & -.24 & -.33 & .08 & 1.00 & & & & & & & & \\
\hline 6 Exch. Ca & $.65^{* *}$ & .12 & .43 & .47 & -.24 & 1.00 & & & & & & & \\
\hline 7 Exch. Mg & .25 & $-.5 \mathrm{I}^{*}$ & -.24 & .31 & .31 & .01 & 1.00 & & & & & & \\
\hline $8 \mathrm{OM}$ & $.80^{* *}$ & -.13 & .34 & $.75^{* *}$ & .24 & $.58^{*}$ & .17 & 1.00 & & & & & \\
\hline $9 \mathrm{pH}$ & .13 & .21 & .00 & -.24 & -.26 & .15 & .23 & -.16 & 1.00 & & & & \\
\hline 10 Avail. & .33 & -.28 & .14 & .21 & -.05 & .13 & .02 & .17 & -.28 & 1.00 & & & \\
\hline $\mathrm{H}_{2} \mathrm{O}^{2}$ & & & & & & & & & & & & & \\
\hline 11 Depth & .02 & .17 & .12 & -.29 & -.28 & .07 & -.30 & .00 & .13 & .06 & 1.00 & & \\
\hline $\mathrm{P}_{0} \mathrm{~S}_{0}$ & .30 & $.59^{*}$ & $.51^{*}$ & .17 & -.25 & .38 & .14 & .09 & .46 & -.02 & .22 & .23 & .38 \\
\hline $\mathrm{P}_{300} \mathrm{~S}_{0}$ & -.04 & $.54^{*}$ & $.52^{*}$ & -.22 & -.34 & .20 & -.47 & -.24 & .04 & -.03 & .11 & -.05 & $.73^{* *}$ \\
\hline $\mathrm{P}_{0} \mathrm{~S}_{30}$ & .12 & $.82^{* * *}$ & $.53 *$ & .01 & .47 & .22 & -.28 & -.11 & .23 & -.13 & .13 & .01 & $.61^{* *}$ \\
\hline$P_{300} S_{90}$ & -.18 & $.82^{* *}$ & $.48^{*}$ & -.28 & -.34 & .12 & $-.55^{*}$ & -.26 & .28 & -.23 & .06 & -.01 & $.80^{* *}$ \\
\hline
\end{tabular}

'Exchangeable cations.

${ }^{2}$ Available water-holding capacity in the soil $\mathrm{A}$ horizon.

*Significant at the $5 \%$ level; ${ }^{*}$ Significant at the $1 \%$ level. 
Table 3. Standardized partial regression coefficients for $k=0.3$ and coefficient of determination in ridge regression relating annual rangeland yields to soil characteristies on 17 range sites.

\begin{tabular}{|c|c|c|c|c|c|c|c|c|c|c|c|c|}
\hline \multirow[b]{2}{*}{$\begin{array}{l}\text { Fertilizer } \\
\text { treatment }\end{array}$} & \multirow[b]{2}{*}{$\begin{array}{l}\text { Soil } \\
\text { depth }\end{array}$} & & \multicolumn{8}{|c|}{ Standard partial regression coefficients $(k=0.3)$} & - & \multirow[b]{2}{*}{$\begin{array}{l}\text { Coef. of det. } \\
\left(R^{2}\right)\end{array}$} \\
\hline & & $\mathbf{N}$ & $\begin{array}{c}\text { Bray-1 } \\
\text { P }\end{array}$ & $\mathbf{K}^{\prime}$ & $\% \mathrm{~S}$ & $\begin{array}{c}\text { Avail. } \\
\mathbf{S}\end{array}$ & $\mathrm{Ca}^{1}$ & $\mathbf{M g}^{1}$ & $\mathrm{OM}$ & $\mathbf{p H}$ & $\begin{array}{l}\text { Avail. } \\
\mathrm{H}_{2} \mathrm{O}\end{array}$ & \\
\hline $\mathbf{P}_{0} \mathbf{S}_{0}$ & .20 & .08 & .33 & .20 & .27 & -.02 & .08 & -.03 & .15 & .37 & .07 & .72 \\
\hline $\mathrm{P}_{300} \mathrm{~S}_{0}$ & .02 & -.10 & .20 & .33 & -.03 & -.07 & .20 & -.16 & -.24 & -.05 & .06 & .57 \\
\hline $\mathrm{PoS}_{90}$ & .11 & .01 & .50 & .19 & .19 & -.21 & .00 & .00 & -.15 & .08 & .02 & .80 \\
\hline$P_{300} S_{90}$ & -.05 & -.15 & .39 & .27 & .01 & -.07 & .06 & -.22 & -.11 & .14 & -.03 & .79 \\
\hline
\end{tabular}

'Exchangeable cations.

fertilizer treatments (Table 3). The following variables were determined to be the most important on the 4 fertilizer treatments in the order indicated:

$$
\begin{aligned}
& \mathrm{P}_{0} \mathrm{~S}_{0}: \text { ph }>\text { Bray-1 } \mathrm{P}>\text { total } \mathrm{S}>\text { exchangeable } \mathrm{K}=\text { soil depth } \\
& \mathrm{P}_{300} \mathrm{~S}_{0}: \text { exchangeable } \mathrm{K}>(-) \mathrm{OM}>\text { Bray- } \mathrm{P}=\text { exchangeable } \mathrm{Ca} \\
& \mathrm{P}_{0} \mathrm{~S}_{90}: \text { Bray-1 } \mathrm{P}>\text { available }(-) \mathrm{S}>\text { exchangeable } \mathrm{K}=\text { total } \mathrm{S} \\
& \mathrm{P}_{300} \mathrm{~S}_{90}: \text { Bray }-1 \mathrm{P}>\text { exchangeable } \mathrm{K}>\text { exchangeable } \mathrm{Mg}
\end{aligned}
$$

Where no fertilizer was applied the considered variables accounted for $72 \%$ of the variation in yield. Each of the factors that showed a significant simple correlation with yield also appeared as important factors in the ridge regression. However, some factors such as pH and total $\mathrm{S}$ that had insignificant simple $r$ values were apparently more importantly related to yield than exchangeable $\mathbf{K}$.

Where $\mathrm{P}$ alone was applied only $57 \%$ of the yield variability was accounted for, and exchangeable $\mathrm{K}$ was most important, followed by $O M$, which was negatively related to yield. The simple $r$ was also negative for OM vs. yield, but the value was not significant. We have no explanation for these negative relationships. Total $S$ and available $S$ were not related to yield in this treatment indicating that the soil tests were not related to $S$ obtained by the plants even though it was a limiting factor for plant growth at 10 of 17 sites.

Eighty percent of the variation in yield was accounted for when $S$ alone was applied. Bray-1 P was by far the most important factor related to these yields, followed by available $S$ and total $S$ which gave conflicting indications (opposite in sign). Exchangeable $\mathbf{K}$ had a modest partial effect on yield.

When both $\mathrm{P}$ and $\mathrm{S}$ were applied we could account for $79 \%$ of the variation in yield. Bray- $1 \mathrm{P}$ was again most closely related to yield, followed by exchangeable $K$ and $\mathrm{Mg}$, the latter being negatively related. Since the soil tests were run on soil sampled before fertilization, the experiments indicate that sites higher in $P$ before fertilization produced more forage after fertilization than those sites which were low in $\mathbf{P}$.

The factors and order of importance were not always as expected. For instance, the application of $\mathbf{P}$ alone would be expected to increase the importance of $S$, but such was not the case. Total soil $S$ or a vailable $S$ showed no significant relation to yield where $P$ was no longer a limiting factor.

Two other inconsistencies were apparent. First, soil depth and pH appeared as important factors related to yield where no fertilizer was applied, but where $P$ and $S$ were not limiting, soil depth and $\mathrm{pH}$ did not appear to be related to yield. Second, total and available $S$ (positive and negative, respectively) were shown to be related to yield where $S$ only was applied, but were not related where $\mathrm{P}$ only was applied.

Site elevation and slope, and soil texture or bulk density are not listed in Tables 2 or 3 as these factors had very low $r$ values and were not found to be related to range production.

It was concluded that soil fertility was more closely related to yield than such physical site-soil factors as slope, elevation, texture, bulk density or water holding capacity over the range of soils tested here. Soil P, as measured by Bray-1 P, was consistently the measurable factor most closely related to subclover-grass range production. Exchangeable $\mathbf{K}$ was also significantly related to production. This should alert range managers in the area to be aware of possible $\mathbf{K}$ deficiencies where range improvement for higher production is the goal. This does not mean that the physical factors are unimportant, but rather that range production can be increased by $P$ and $K$ fertilization within the limitations of the physical factors extant. The response to $S$ fertilization indicated that it was deficient. However, soil tests for $\mathrm{S}$ used in this study appeared to be of little diagnostic value.

\section{Literature Cited}

Barrow, N.J. 1967. Studies on extraction and on availability to plants of adsorbed plus soluble sulphate. Soil Sci. 104:242-249.

Bray, R.H., and L.T. Kurtz. 1945. Determination of total, organic, and available forms of phosphorus in soils. Soil Sci. 59:39-45.

Bremner, J.M. 1965. Total nitrogen. In: Methods of soil analysis. Part 2. C.A. Black et al. (ed.) Agronomy 9:1 149-1178. Amer. Soc. Agron. Madison, Wis.

Gardner, E.H., T.L. Jackson, W. Mosher, L. Cannon, W.S. McGuire and T.E. Bedell. 1979. Oregon State University fertilizer guide for subclovergrass pastures - Western Oregon. Oregon State Univ. Extension Serv. Pub. FG 4.

Johnson, C.M., and H. Nishita. 1952. Microestimation of sulfur in plant materials, soils and irrigation waters. Anal. Chem. 24:736-742.

Jones, M.B. 1974. Fertilization of annual grasslands of California and Oregon. p. 255-275. In: Forage Fertilization. D.A. Mays (ed.) Amer. Soc. Agron., Madison, Wis.

Jones, M.B., J.C. Burton, and C.E. Vaughn. 1978. Role of inoculation in establishing subclover on California annual grassland. Agron. J. 70: 1081-1085.

Jones, M.B., J.E. Ruckman, W.A. Williams, and R.L. Koenigs. 1980. Sulfur diagnostic criteria as affected by age and defoliation of subclover. Agron. J. 72: 1043-1046.

Kauffman, M.D., and E.H. Gardner. 1976. Methods of soil analysis used in the soil testing laboratory at Oregon State University. Oregon Agr. Exp. Sta. Spec. Rep. 321.

Love, R.M. 1955. Grassland improvement, a vast profit potential. Agr. \& Food Chem. 3:306-309.

Martin, W.E. 1958. Sulfur deficiency widespread in California soils. California Agr. 12:10-12.

Martin, W.E., and L.J. Berry. 1970. Effects of nitrogencus fertilizers on California range as measured by weight gains of grazing cattle. California Agr. Exp. Sta. Bull. 846.

Reisenauer, H.M. 1975. Soil assays for the recognition of sulfur deficiency. p. 182-187. In: Sulphur in Australasian Agriculture. K.D. McLachlan (ed.) Sydney Univ. Press, Sydney, Australia.

Spencer, K., and J.S. Glendinning. 1980. Critical soil tests values for predicting the phosphorus and sulfur status of subhumid temperate pastures. Aust. J. Soil Res. 18:435-445.

Vaughn, C.E., and M.B. Jones. 1980. Soil phosphorus tests on California subclover-annual grass pastures. Soil Sci. 130:307-313.

Williams, W.A., M.B. Jones, and C.C. Delwiche. 1977. Clover N-fixation measurement by total-N difference and is $\mathrm{N}$ A-values in lysimeters. Agron. J. 69:1023-1024.

Williams, W.A., C.O. Qualset, and S. Geng. 1979. Ridge regression for extracting soybean yield factors. Crop Sci. 19:869-873. 